\title{
PRODUÇÃO DO ESPAÇO, AUTOGESTÃO, COMUNIDADE E ESTADO: PROVOCAÇÕES A PARTIR DE KARL MARX
}

\author{
Alvaro Ferreira* \\ Pontifícia Universidade Católica do Rio de Janeiro \\ Universidade do Estado do Rio de Janeiro
}

Resumo: 0 objetivo deste artigo é analisar, a partir de certas obras de Karl Marx, a construção de possibilidades para além do que se tem apresentado sobre a produção do espaço, com o fim de que esta se dê com mais justiça social. Discorre-se assim sobre ferramentas políticas e de gestão existentes, mas também, e principalmente, de outras possibilidades que remetem a "um impossível possível", nos termos de Henri Lefebvre. Para tanto, são trazidas para o debate as noções de comunidade, verdadeira democracia, autodeterminação, autogoverno, autoemancipação e autogestão, tal como veiculadas na obra de Karl Marx.

Palavras-chave: Produção do espaço. Estado. Comunidade. Autogestão. Karl Marx.

\section{GPRODUCTION OF SPACE, SELF-MANAGEMENT, COMMUNITY AND STATE: PROVOCATIONS FROM THE KARL MARX WORK}

Abstract: From certain works of Karl Marx, the article deals with an analysis of the construction of possibilities beyond what exists, for the purpose that the production of space brings social justice. We will discuss existing policies and management tools, but also and especially the other possibilities, referring to an "impossible possible", in Henri Lefebvre's terms. Therefore, we will bring to the debate the notions of community, true democracy, self-determination, self-government, self-emancipation and self-management based on Karl Marx's theory.

Keywords: Production of space. State. Community. Self-management. Karl Marx.

\section{PRODUCCIÓN DEL ESPACIO, AUTOGESTIÓN, COMUNIDAD Y ESTADO: PROVOCACIONES A PARTIR DE KARL MARX}

Rsumen: El objetivo de este artículo es analizar, a partir de ciertos trabajos de Karl Marx, la construcción de posibilidades más allá de lo que existe, con el fin de que la producción del espacio se dé con más justicia social. Por lo tanto, hablamos de las herramientas políticas y de gestión existentes, pero también, y principalmente, de otras posibilidades que se refieren a "un imposible posible", según Henri Lefebvre. Para ello, traemos para el debate las nociones de comunidad, verdadera democracia, autodeterminación, autogobierno, autoejecutación y autogestión basadas en el trabajo de Karl Marx.

Palabras clave: Producción del espacio, Estado. Comunidad. Autogestión. Karl Marx. 
Introdução... ou provocações iniciais...

A produção da cidade, desde muito tempo, se faz como instrumento de viabilização do momento histórico da sociedade; fato explicável, pois o espaço é produzido socialmente. Entretanto, se não restam dúvidas de que a cidade é um produto social, isso não se dá sem tensões. Há forte jogo de poder envolvido, em que os diferentes atores sociais procuram impor o seu projeto.

Nosso objetivo é analisar a construção de possibilidades de produção da cidade para além do que tem se apresentado, com o fim de que a produção do espaço se dê com mais justiça social. Utilizaremos, para tanto, a construção de um diálogo a partir de, principalmente, quatro obras de Karl Marx: "Crítica da filosofia do Direito de Hegel", "A guerra civil na França", "Crítica do programa de Gotha" e "O Dezoito Brumário de Louis Bonaparte". A partir daí, trataremos de introduzir questões relativas à tensão entre Estado e Sociedade Civil, ao desvanecimento do Estado, à instauração da comunidade e daquilo que Marx denominou de verdadeira democracia. Permitir-nos-emos discorrer sobre outras possibilidades, que remetem, talvez, a um impossível possível; nesse sentido, trabalharemos também com as noções de autodeterminação, autogoverno, autoemancipação e autogestão.

E por que ainda falar em Karl Marx no início do século XXI? Porque apesar dos inumeráveis discursos que afirmam que o comunismo defendido por Marx é antiquado e fracassado (principalmente porque se baseiam em experiências ditas socialistas que efetivamente não representavam os ideais de Marx), a sua construção teórica acerca da revolução ainda é muito valiosa e nos mostra a importância de seu sentido antiautoritário e verdadeiramente democrático, além de valorizar e reafirmar as potencialidades emancipadoras no interior da sociedade. E não à toa podemos encontrar na obra "A guerra civil na França" afirmações muito fortes indicando que a revolução emancipadora somente poderia ser "um governo do povo pelo povo" e que teria que ser "a retomada pelo povo e para o povo de sua própria vida pessoal". Marx mirava o desvanecimento do Estado e de toda a sua maquinaria, com a criação de instituições adequadas ao autogoverno popular.

A expressão "impossível possível" se coloca neste debate justamente para escapar de discursos que afirmam a inevitabilidade do modelo vigente, para escapar dos discursos que desqualificam as propostas diferentes, que afirmam tratarem-se de um plano que parece irrealizável, fantasia, quimera, sonho.

Embora grande parte dos chamados projetos utópicos tenham sido vistos ou tratados como impossíveis, por que temos que os pensar apenas como impossíveis? Acreditamos ser necessário e fundamental continuar buscando algo diferente e melhor.

Há tempos, Boaventura de Sousa Santos (1997, p. 323) acredita que precisamos explorar "novas possibilidades e vontades humanas, por via da oposição da imaginação à necessidade do que existe, só porque existe, em nome de algo radicalmente melhor que a humanidade tem direito de desejar e pelo que vale a pena lutar". É preciso pensar no direito à produção do espaço. É preciso arriscar, e é preciso acreditar nas ideias. Acreditava Sartre que uma ideia, antes de ser efetivamente realizada, se pareceria estranhamente com a utopia. Por isso, no decorrer desta reflexão, tentaremos pensar naquilo que muitas vezes é visto como impossibilidade, de outra maneira acabamos permanecendo imobilizados e reproduzindo aquilo que criticamos.

Produção do espaço e a possibilidade de construção de algo diferente

Atualmente é possível percebermos uma certa distorção da expressão "direito à cidade", trabalhada por Henri Lefebvre (1991) em 1968. Esta expressão que teria o poder de unir a academia através de vários campos científicos, como a Geografia, Sociologia, Ciência Política, Arquitetura, Direito e também órgãos governamentais e a sociedade de forma geral tem sido distorcida. Inclusive é a percepção disso que leva Ana Fani Alessandri Carlos $(2016$, p. 1) a afirmar que "o direito à cidade acha-se esvaziado de sua potência utópica", o que dificulta "a possibilidade de construção de um projeto social que oriente as ações em direção ao futuro da sociedade, como o negativo da realidade em que vivemos". Entretanto, acredita Carlos (2016, p. 2) que o pensamento utópico se alimenta da existência de forças criativas e na própria consciência da existência da alienação.

O direito à cidade não pode referir-se apenas a simples área construída, deve ser visto ademais como o lugar da inclusão e da dinâmica cultural, construído a partir de uma miríade de individualidades, como espaço das diferenças, da multiplicidade de usos.

0 direito à cidade é mais do que um habitat, é o direito a habitar. $\mathrm{O}$ habitat liga-se à morfologia urbana, mas o habitar é uma atividade; referimo-nos à apropriação. Habitar é apropriar-se de algo, o que é bastante diferente de tê-lo como propriedade. Significa fazer do espaço sua obra, modelá-lo, apropriar-se dele. Mas ele é tam- 
bém o lugar dos conflitos, porque o espaço é um produto social. É também "produtor", já que as formas construídas interferem no cotidiano da sociedade. A produção do espaço traz consigo uma intencionalidade, por isso é o lugar dos conflitos. É preciso questionar a forma como ele é produzido e buscar fazê-lo de outra maneira, com outros objetivos que não priorizem a especulação e a dominação do espaço. Em outras palavras: para mudar a vida é preciso mudar o espaço, é preciso questionar a propriedade privada do solo, é preciso valorizar o espaço público e lutar por ele. Porque, como afirma Lefebvre (2008) "excluir do urbano grupos, classes ou indivíduos implica também excluí-los da civilização, até mesmo da sociedade".

Lefebvre $(2013,1999)$, ao refletir sobre o urbano e sobre o fato de que ele transcende à cidade, percebe que mais do que pensar no direito à cidade, melhor seria refletir sobre o direito à produção do espaço. Assim, quando Lefebvre elabora a perspectiva da luta pelo direito à cidade, tinha em mente a superação do capitalismo. Acreditava ser necessário a construção de outra racionalidade para a constituição de uma outra sociedade. Lefebvre buscava orientar o pensamento marxista com o objetivo de perceber o crítico papel que as relações de propriedade desempenham no sistema capitalista, além de também construir um discurso radical pela produção de um espaço próprio que contribuísse para a transformação da vida cotidiana; até porque uma coisa está relacionada à outra.

O espaço é um produto social, e nesse sentido é fruto das práticas e relações sociais, mas simultaneamente é suporte e interfere no cotidiano, já que é produzido com intencionalidades. Em outras palavras, enquanto produto, o próprio espaço interage com sua própria produção, por isso Lefebvre trabalhava com a ideia de espaço como produto-produtor. Passamos por um momento em que vivenciamos a mercadificação generalizada das relações sociais, pois não se trata apenas da mercantilização, do processo de troca, mas a própria ação torna-se ela mesma uma mercadoria. Ao falarmos de mercadificação do espaço, significa dizer que ele é mercantilizado, mas que essa mercadoria que estamos comprando é cada vez mais um estilo de vida, uma experiência cotidiana dita diferenciada, compramos o que representa ter aquilo, fazer parte daquilo, estar em determinado lugar. Vivemos uma fase em que se acirra a lógica do regime de acumulação financeira, na qual a financeirização do capitalismo em escala global se junta a todos os aspectos da atividade econômica, das práticas sociais e da política dos Estados.

Já na década de 1970, acreditava Lucien Goldmann (1977, p. 139) que, no mundo capitalista, a religião, a moral, a arte e a literatura também tendem a se transformar em mercadoria "à medida que sua autenticidade vai sendo esvaziada por dentro, graças à aparição de um conjunto econômico autônomo que tende a se apossar de modo exclusivo de todas as manifestações da vida humana". Tudo passa a ser factível de ser consumido, e isso cresce de tal modo que o endividamento crônico torna-se natural, torna-se um modo de vida. Dentro dessa lógica, também o lazer encontra-se cada vez mais ligado aos espaços privados.

Não é possível vivenciarmos tudo isso sem um olhar crítico acerca da dominação do espaço. É preciso lutar pela participação, mas participar não se limita a opinar sobre um determinado projeto, supõe também a vontade de intervir na produção do espaço. A participação cidadã, como já vimos afırmando há mais de uma década, conecta a pessoa com a coisa pública e isso não deve acontecer apenas nos marcos institucionais do Estado, deve partir da sociedade organizada. E se tivermos em conta o que afirmou Karl Marx acerca da participação, entenderíamos que todas as atividades individuais passariam a ter um sentido público, já que diriam respeito à gestão coletiva da comunidade.

É preciso construir propostas de mudanças nos processos de decisão, mas também relativas à construção de espaços - no sentido concreto mesmo de diálogo e de decisões, visto que, de alguma maneira, nós produzimos o espaço que nos produz. Para tanto, é preciso pensarmos o espaço também como política. É preciso pensar em outras formas de planejamento, baseadas no diálogo e na participação democrática, pois como diz Capel (2003), "não podemos deixar que sejam os técnicos que nos dirijam, que nos ponham diante do fato consumado. Temos que impor o diálogo, tornar explícitas nossas opções e pôr os técnicos a nosso serviço". Aqui, embora não seja isso necessariamente o que Horacio Capel propõe, valeria a pena pensarmos na ideia de autogestão.

\section{Autogestão? Por que ainda é preciso falar em Marx?}

Durante muito tempo convivemos com problemas relativos à pouca oferta das obras do denominado "jovem Marx" e por uma fixação em sua obra de maior fôlego "O Capital". Além disso, muitos leitores viramse influenciados por um discurso que apresentava a "existência de dois Marx", já que para Althusser (1969) teria havido o "humanista e ideológico" da juventude e o "Marx marxista da maturidade". E pior: afirmava que seria apenas na "fase científica", em sua análise do capitalismo, que Marx se torna imprescindível e que sua 
"primeira fase" pode ser esquecida. Estas afirmações construíram, inclusive, a ideia de que a produção intelectual inicial de Marx era desconectada da obra da maturidade, o que não é verdade.

O estudo do Estado e da política estava nos planos de Marx, até porque o planejado era retomar a filosofia política a partir de suas investidas na economia política. Aliás, no prefácio dos Manuscritos EconômicosFilosóficos (2004, p. 19), escrito em 1844, Marx - apenas com 26 anos - já apontava para o plano de sua obra ao afirmar que faria

sucessivamente, em diversas brochuras
independentes, a crítica do direito, da moral, da
política etc., e por último, num trabalho específico, a
conexão do todo, a relação entre as distintas partes,
demarcando a crítica da elaboração especulativa
deste mesmo material. Assim, será encontrado o
fundamento, no presente escrito, da conexão entre a
economia nacional e o Estado, o direito, a moral, a vida
civil (bürgerliches Leben) etc.

Evidentemente, sabemos que Marx não conseguiu realizar seu plano de trabalho, então estamos falando de uma obra inacabada. 0 próprio autor chegou a afirmar que pretendia escrever um livro em seis volumes, em que $O$ Capital era apenas o primeiro (e como sabemos este também ficou incompleto). Esses seis volumes seriam: 0 capital; A propriedade da terra; 0 trabalho assalariado; O Estado; 0 comércio exterior; e 0 mercado mundial. Embora o projeto tenha sido inacabado, Marx deixou escritos alguns fragmentos de textos que nos permitem ao menos elaborar algumas provocações acerca da alienação, do desvanecimento do Estado, da autogestão, da democracia e da própria noção de comunidade.

0 resgate dessa reflexão realizada por Karl Marx na primeira metade do século XIX e retomada por ele em 1871, na obra intitulada "A guerra civil na França", não deve e nem pode ser retomada sem a devida contextualização com o momento atual. Tal falta de cuidado seria "engessar" o tempo e esquecer que Marx falava como pensador de seu tempo e refletia sobre a realidade europeia; aliás, sobre determinada parcela da realidade do continente, mais especificamente, Inglaterra, França, Bélgica e parte do que viria a ser a Alemanha. Ou seja, retomar Marx não significa tomar seus escritos de forma dogmática, mas avançar a partir dele e tentar contribuir para a projeção de outra possibilidade de mundo.

Tendo a certeza de que refletimos sobre o mundo a partir da nossa história e influenciados pelos acontecimentos que estão em curso, é preciso entender que Marx e Engels, quando puseram-se a pensar sobre como a política e o Estado eram instâncias supremas da alienação, idealizaram um caminho para escapar dessa dominação. Sendo um homem do seu tempo, Marx foi muito impactado pela Revolução Francesa e pelos desdobramentos da industrialização inglesa no século XIX, e acabou acreditando que a completa destruição do antigo regime e a superação daquelas situações de trabalho e de vida urbana poderiam ser rapidamente alcançadas.

A despeito de que haja uma cobrança acerca da falta de uma teoria marxista de Estado, é interessante acompanhar a reflexão de Atilio Boron (2006, p. 312) quando afirma que "a teoria marxista de Estado é, na realidade, uma teoria da 'extinção do Estado", uma teoria da reabsorção do Estado pela sociedade civil plasmada na fórmula do 'autogoverno dos produtores '." Portanto, parece ao menos questionável o discurso que afirma ter sido Marx um defensor de um Estado autoritário e centralizador. Acreditava ele que "o Estado era, e é, uma entidade parasitária cuja permanência depende da sobrevivência de uma sociedade de classes" (BORON, 2006, p. 313). Importa esclarecer que o desvanecimento do Estado não significa fim da administração pública, e acreditamos que isto ficará mais claro adiante.

Marx (2005), na busca da verdadeira democracia, acreditava que era necessário opor à burocracia a alternativa da autogestão. Chegar à verdadeira democracia, para Marx, significava caminhar para o desvanecimento do Estado (e nesse caso, necessariamente, para o fim do seu contraponto: a sociedade civil), o que levaria à constituição da comunidade.

Encaminhar-se-ia em direção a uma espécie de autogoverno, já que cada indivíduo governaria a si mesmo, assim, a comunidade como um todo se autogovernaria. Haveria funções sociais e administrativas que continuariam a ser exercidas, mas não mais como funções estatais. Marx (2012) referir-se-ia a elas como funções sociais análogas àquelas do Estado, mas não idênticas (nem coercitivas ou opressoras), pois se tornariam funções públicas. Nesse sentido, sendo funções públicas, as funções governamentais transformar-se-iam em funções administrativas. Para Marx, assim, a autoridade estatal cederia lugar à autonomia, isso porque a divisão das funções gerais transformar-se-ia em algo tão natural e rotineiro, que não concederia qualquer autoridade.

A proposta de Marx, verdadeiramente, talvez até por não ter sido totalmente elaborada, nunca foi posta em prática, mas não nos resta dúvida de que é bastante empolgante e inquietadora. Pensar que os cidadãos passam a ter várias atividades para vivenciar o ser político em plenitude, e também que a atividade dos homens à 
semelhança do que ocorre com a autodeterminação e o autogoverno (de si mesmo e, então, de todos) é que explica a autogestão é no mínimo um convite à ação. Com isso se alcançaria a possibilidade de conciliar as duas principais perspectivas na análise territorial: a mais funcional (que tem servido mais aos aparatos de controle) e a mais simbólica, que, se levada em consideração, oferece alternativas para formas de gestão mais democráticas e mais justas socialmente. As duas escalas têm de ser conectadas em novas formas de (auto)gestão territorial, isto é, ligadas à vida no lugar.

Marx (2005), na obra "Crítica à Filosofia do Direito de Hegel", deixa inúmeras pistas e encaminhamentos sobre o que denominou de desvanecimento do Estado. Acreditava ele que o Estado desapareceria porque em seu lugar surgiria a verdadeira democracia, em que uma nova forma de organização política tomaria lugar. Marx falava-nos de um movimento simultâneo em que a sociedade civil ganharia força e aumentaria sua participação e o Estado, por sua vez, desvaneceria. Esse processo aconteceria justamente porque haveria um movimento de aproximação entre essas duas esferas, 0 que contribuiria para a dissolução de ambos: Estado e sociedade civil. Marx acreditava que somente existiria sociedade civil em contraposição ao Estado e este em contraposição àquela; assim, a dissolução de um leva sistematicamente à dissolução do outro, já que suas existências individuais são sustentadas pela sua relação de oposição. Acreditava ele, também, que a própria emancipação política dar-se-ia pela dissolução da antiga sociedade sob a qual repousa o Estado, porque se tratava da superação do Estado.

A ideia de revolução é parte integrante desta estrutura de pensamento, pois é um ato político com fim social, já que procura dissolver a velha ordem da sociedade e também o velho poder governante. Vamos assim ao encontro do sociólogo Michael Löwy (2012, p. 20), que acredita que a teoria marxiana da revolução como autoemancipação dos explorados "continua a ser uma bússola preciosa para o pensamento e a ação". A autoemancipação era, para Marx, um aspecto intrínseco do movimento ao comunismo. Assim, é possível percebermos porque tentativas de "construção do socialismo 'sem o povo (ou contra ele), 'emancipação' do trabalho de cima para baixo, imposição de uma nova sociedade pelos decretos de um poder burocrático e autoritário estava inevitavelmente destinada ao fracasso" (Löwy, 2012, p. 21). Marx acreditava que o ser político somente teria autonomia e viveria seu sentido público, naquilo que denominou comunidade (um lugar que não é nem o do Estado e nem o da sociedade civil). E aqui, não se trata de pensar que após o fim da antiga sociedade haveria uma nova dominação de classe culminando em um novo poder político; seria outra coisa. Muitas vezes, partidos de esquerda pensam em estar no poder, em assumir a maquinaria estatal, outras vezes preconizam o retorno do keynesianismo ou do compromisso social-democrata; não foi esse o caminho idealizado por Marx.

Estamos falando através de uma perspectiva de algo realmente novo, e o que Marx afirmava era que a verdadeira ideia de abolição do Estado não poderia se apoiar no próprio Estado; o que haveria de surgir com o desvanecimento do Estado teria de ser algo novo. Dessa maneira, não se trata de mudar quem está no poder, ou remetendo-nos ao século XIX, à conquista do Estado pelo proletariado, e isso parece claro e cristalino quando Marx (2006) afirma que o problema dos levantes revolucionários tem sido o fato de não entender que para o Estado ter fim, é preciso que ele realmente deixe de existir. Isso se exemplifica pelos próprios partidos de esquerda, que ao chegarem ao poder utilizaram-se do próprio aparato do Estado como a principal recompensa pela vitória. Acreditamos, a partir de Marx, que o fracasso das revoluções ocorreu exatamente porque ao invés de abolir o Estado, elas acabaram reforçando o Estado, mesmo que, muitas vezes, tivessem o objetivo de melhorá-lo. Talvez, porque "o como fazer isso" não tenha sido totalmente desenvolvido por Marx, é que Engels tenha desenvolvido uma construção mais instrumental, que não condiz com a proposta original de Marx, tornando-se, talvez, o primeiro vulgarizador de suas ideias, mas retornaremos a esse debate mais à frente.

Aqui é preciso fazer uma observação importante: quando falamos em retorno a Marx, devemos fazêlo sem a ilusão de encontrar nele todas as respostas; e mais, precisamos nos permitir criticar determinadas posições e avançar a partir de seus escritos. Marx foi um grande pensador, mas tinha também em seu horizonte a dimensão da ação (lembremo-nos da máxima "compreender para transformar") e, por vezes, contradições que são naturais do ser humano também nele transparecem. Talvez a mais questionada $\mathrm{e}$ contestada das expressões utilizadas seja a de "ditadura do proletariado"'.

A palavra ditadura tem sua raiz etimológica no particípio latino dictus, que significa dizer, ditar ou indicar, e pelo sufixo ura, que se refere à atividade ou ao resultado concreto de algo. Dessa forma, a palavra ditadura significaria "o resultado do que uma pessoa

'É possível encontrar um debate bem mais aprofundado sobre "ditadura do proletariado", Marx e marxismo em um trabalho intitulado "A luta pela 'verdadeira democracia' na produção do espaço: por outro projeto de sociedade" (Ferreira, 2019). 
diz ou indica". Segundo o dicionário Houaiss da Língua Portuguesa, ditador era o título de um magistrado romano escolhido pelo senado de Roma para governar o Estado em tempo de emergências. 0 período no poder não podia ser maior do que seis meses. A ditadura não era algo a quem alguém se arrogasse, era uma função extraordinária e totalmente legal. Por outro lado, em sentido figurado, a palavra ditadura serve também para designar uma excessiva influência que alguém ou algo exerce sobre a população, e que possui uma espécie de autoridade absoluta.

É preciso ter em conta o contexto histórico em que Marx e Engels trazem à tona a expressão "ditadura do proletariado". A expressão surge como contraposição àquilo que denominaram ditadura da burguesia ou da ditadura do Capital. Ademais, Marx afirmava que toda forma de poder estatal é uma forma de ditadura de classe. E nesse sentido foi possível afirmar que a democracia burguesa era ela própria uma ditadura de classe. Assim, percebemos de fato algum exagero naqueles que supervalorizam a expressão "ditadura do proletariado" e outras assemelhadas como, por exemplo, a "ditadura democrática do proletariado". Isto porque em um certo sentido, para Marx, ditadura era a primazia de uma classe no controle; ditadura não era necessariamente o arbítrio ou a excepcionalidade. Por isso, quando Marx falava da ditadura burguesa, fazia referência ao caráter de classe burguesa do Estado; ou seja, Marx usou a palavra ditadura para caracterizar a ideia de conteúdo político do Estado (aliás, nesse sentido, não à toa, Marx fala em "ditadura democrática do proletariado", o que sinaliza que não se tratava de uma forma autoritária). Por isso, de alguma maneira, poderíamos dizer que a instauração da experiência socialista fez muito mal à ideia do que seria o comunismo. Não é possível continuarmos a acreditar que o socialismo é uma fase que antecederia ao comunismo, isso porque, na verdade, é sua maior ameaça, já que acaba fazendo o papel de seu concorrente. Tentando ser mais claro, e recorrendo ao filósofo esloveno Slavoj Zizek (2011, p. 86), podemos afirmar que "a única maneira de o sistema capitalista global sobreviver a seu antagonismo de longo prazo e, ao mesmo tempo, evitar a solução comunista é reinventando algum tipo de socialismo - sob o disfarce de comunitarismo, populismo, capitalismo de valores asiáticos ou alguma outra configuração".

Ao contrário do que se possa pensar, a expressão ditadura do proletariado não surge no Manifesto Comunista; aliás, essa expressão nem é utilizada no Manifesto. 0 fato é que Marx utiliza poucas vezes essa expressão e sequer trata de conceituá-la com precisão. Em geral, a utilização da expressão ditadura do proletariado, por Marx, foi realizada em cartas ou documentos não previstos para publicação (com exceção de "As lutas de classes na França de 1848 a 1850" e "Crítica do Programa de Gotha" de 1875). Na verdade, Marx não explica muito bem o conceito de ditadura do proletariado. Ele chega a afirmar que "entre a sociedade capitalista e a comunista, situa-se o período da transformação revolucionária de uma na outra. A ele corresponde também um período político de transição, cujo Estado não pode ser senão a ditadura revolucionária do proletariado" (2012, p. 43). Em 1871, Marx havia escrito uma espécie de panfleto intitulado Guerra civil na França, onde também apresentava a ideia de ditadura do proletariado. Ali afirmara que o aspecto mais relevante da Comuna de Paris, ao contrário de todas as revoluções anteriores, estava no fato de ter iniciado o desmonte do aparelho de Estado através da transferência do poder para o povo. Ele percebeu a instituição da Comuna como uma tentativa de criação de um regime o mais próximo possível de uma democracia direta. Marx aproximava a noção de ditadura do proletariado de uma forma de governo em que a classe trabalhadora realmente governaria e se incumbiria de muitas das atividades até então executadas pelo Estado. Ou seja, o proletariado estaria exercendo a hegemonia que a burguesia exercia até então, mas revolucionando a forma de participação e engajamento.

Em nenhum momento a ideia de ditadura do proletariado é conceituada por Marx como uma forma de manutenção do Estado, até porque ele defendia o seu desaparecimento, sua dissolução gradual. Para Marx, o conceito de desvanecimento do Estado é incompatível com a ideia de ditadura. A mesma incompatibilidade se dá com a expressão Estado proletário. Aliás, a posição de Marx parece bastante clara em dois textos escritos por ele em 1873 e em 1874; "Indiferença em matéria política" e "Comentários de Marx a Estatismo e Anarquia de Bakunin", respectivamente. Nesta segunda obra Marx define verdadeiramente aquilo a que se está referindo como "proletariado organizado como classe governante", e que equivocadamente acaba equiparada a uma ditadura do proletariado.

Afirma Marx que a ideia de proletariado organizado como classe governante "significa que o proletariado, em vez de lutar seccionalmente contra a classe economicamente privilegiada, alcançou força e organização suficientes para empregar meios gerais de coerção nessa luta". Mas acrescenta ainda que, "no entanto, ele só pode usar tais meios econômicos conquanto abole seu próprio caráter como assalariado, portanto, como classe. Com sua vitória completa, seu próprio governo também acaba, já que seu próprio 
caráter de classe desaparece". Importante acrescentar que na sequência de suas afirmações Marx aproxima aquilo que denominou de "meios gerais de coerção" à ideia de "função administrativa". A participação tornarse-ia totalmente natural para o ser político, o que contribuiria para não o tornar superior aos demais.

Assim, desmontando as bases materiais que conformam a sociabilidade burguesa, desmontam também as suas formas jurídico-políticas. Esse processo levaria a uma hegemonia de formas não-capitalistas e de desalienação progressiva da sociedade, além de caminhar em direção da ideia de emancipação humana, o que traria à tona a dimensão do ser político. Para a realização da emancipação humana seria necessário a implantação da noção de comunidade e da verdadeira democracia, que contribuiriam para a desalienação.

Embora essa posição seja bem clara em Marx, o discurso de Engels era mais ambíguo e mesmo diferente da concepção defendida por Marx. Engels apresentava a ideia de abolição gradativa do Estado pelo proletariado; assim, defendia a ideia de que o Estado poderia ser usado como meio de sua própria abolição. É possível perceber, então, diferenças importantes na posição defendida por esses autores. Aliás, nesse sentido o caminho trilhado por Lenin aproximou-se muito mais de Engels do que de Marx. Inclusive, Marx não falava em partido político, e a apropriação da expressão "ditadura do proletariado" feita na Rússia acabou distorcendo ainda mais essa expressão, chegando inclusive a um despotismo ilimitado. De fato, houve uma considerável diferença entre o que Marx considerou "ditadura democrática do proletariado" e o que Lenin acabou instituindo na Rússia: a ditadura do proletariado sob a direção do partido. Nesse sentido, é difícil acreditar que tenha efetivamente sido posto em prática, de fato, o comunismo em algum país, até porque sem a instituição da verdadeira democracia, a alegação de que o povo era possuidor dos meios de produção é claramente falsa.

Acreditamos já ter deixado claro até aqui, que a proposta de Marx via a possibilidade de chegada ao comunismo como um processo, que se realizaria através do desvanecimento do Estado. Isso em nenhum momento significava, para Marx, a manutenção do Estado pelo proletariado. Ao contrário, acreditava ele na necessidade de destruição da maquinaria do Estado. Voltamos a afirmar que não se tratava da mera mudança daqueles que estariam a frente do governo. Era necessário construir outra coisa, algo novo que possibilitasse o nascimento da verdadeira democracia e com ela a ideia de comunidade.

A ideia do fim do Estado em Marx está intimamente ligada à autonomia, que se encontra ligada à autodeterminação e ao autogoverno. Marx não trata a noção de autonomia como simples oposição à autoridade, pois acreditava que a luta deveria ser pelo fim do Estado e, consequentemente, sua autoridade. A cientista política Thamy Pogrebinschi (2009, p. 75), procurando desenvolver tal debate, afirma que a "ideia de autoridade esvazia-se, deixa de ter sentido, pois não há espaço para ela quando o que se tem é um estado de coisas no qual a comunidade em si se autogoverna porque cada uma de suas partes componentes, os homens, também se governam". A partir de então é possível entender porque a autora afirma que "o autogoverno das comunidades que Marx vislumbra como aquilo que sucederá ao fim do Estado consiste, assim, em uma espécie de autogoverno do autogoverno dos homens". Nesta perspectiva é possível compreender porque não há como pensar separadamente autonomia individual e autonomia coletiva ${ }^{2}$ a partir de Marx.

Não há como pensar em transformação da forma de gestão sem pensar em mudanças sociais e econômicas, e também na construção de novos espaços de debates. Isto porque Marx acreditava que a superação do Estado e da sociedade civil se daria através da constituição da comunidade, já ela que traz em si tanto o Estado como a sociedade civil, mas simultaneamente elimina ambos. A comunidade em seu conteúdo não é nenhum deles, embora em sua forma ela possa ser os dois.

A comunidade seria uma nova forma de organização da sociedade, dos seres políticos. Marx colocava o ser político em contraposição à política instituída. Acreditava ele que a implementação desse projeto levaria à redução das funções ligadas a um governo central, porque a luta da comunidade deveria ser contra o Estado (objetivando sua superação) e, portanto, a valorização da autonomia e dos lugares levaria à certa descentralização. Assim, cada vez mais a ideia de verdadeira democracia, desenvolvida por Marx em meados dos anos de 1840, aproxima-se da ideia de comunidade, mais desenvolvida em seus escritos do início da década de 1870, inspirado pela Comuna de Paris. A maior parte dos pesquisadores ainda acredita que o Estado teria a função de "controlar" os mercados; entretanto, o que temos visto é que ele tem trabalhado senão como produtor, ao menos como viabilizador da criação de "normas de competitividade, à custa de todas as considerações de salvaguarda das condições mínimas de bem-estar, saúde e educação

${ }^{2}$ Embora afirmando-se crítico de uma determinada perspectiva de alguns autores marxistas, Cornelius Castoriadis (1982) desenvolve importante debate acerca da categoria autonomia, mas que de certa maneira não rompe com aquilo colocado, embora mais superficialmente, por Marx. Na Geografia, Marcelo Lopes de Souza apropria-se do debate desenvolvido por Castoriadis e promove importantes associações entre autonomia e espacialidade, por exemplo no livro "Por uma Geografia Libertária" de 2017. Entretanto, não temos por objetivo alongarmo-nos na discussão realizada por Marcelo Lopes de Souza, já que nos debruçamos como afirmado na introdução do artigo - basicamente sobre as obras de Karl Marx. 
da população" (DARDOT, LAVAL, 2016, p. 31), além de defender e auxiliar o sistema financeiro, por exemplo, na crise de 2008. Nesse sentido, afirmam esses autores que "o Estado neoliberal não é um 'instrumento' que se possa utilizar indiferentemente para finalidades contrárias. Enquanto 'Estado-estrategista', co-decididor dos investimentos e das normas, ele é uma peça da máquina que se deve combater".

Se buscamos aquilo que ainda não existe, as reflexões de Marx vão ao encontro do novo; do impossível possível, se verdadeiramente considerado como horizonte a ser alcançado. Aqui não há como não recordar Lefebvre quando afirmava que para alcançarmos o possível temos que mirar o impossível. Assim, ao pensar no rompimento com o Estado, a forma política propiciada pela formação da comunidade surge do novo, e a partir daí, a verdadeira democracia juntamente com a emancipação humana se encontrariam e se realizariam naquilo que Marx chamou de comunismo.

Evidentemente, estamos falando de algo que não se realizou (ainda). Quando falamos da superação do Estado, referimo-nos ao conceito de Estado moderno e de sua forma de organização, inclusive a maneira como se dá o agir político. Não se trata de fazer uma revolução para transferir o poder de uma fração de classes governantes para outra, mas para derrubar a maquinaria da própria dominação de classe (MARX, 2011). Para Marx, o Estado precisava existir, justamente para percebermos que ele não funcionava e precisava ser superado. É a partir desta consideração que Pogrebinschi (2009, p. 167) afirma que "a comunidade é o antiestado e, ao mesmo tempo, o pós-Estado. Ela ganha existência quando o Estado deixa de existir, e só quando ele deixa de existir". Por isso, mesmo sem se valer dos instrumentos do Estado, a comunidade nasceria de sua ruína; o que corrobora com o discurso de Marx (2011), quando afirmava que a sociedade comunista surgiria da própria sociedade capitalista. Isso porque não acreditava que Estado e democracia combinassem.

$\mathrm{Na}$ utopia que vai em direção a uma sociedade comunista, não resta dúvida que existiriam funções de governo (até porque Marx nunca imaginou que no comunismo não houvesse governo), mas partia da ideia de um autogoverno e não de um governo que partisse do Estado; tratar-se-iam de funções sociais.

A chegada ao momento da sociedade comunista dar-se-ia através de uma revolução, que para Marx, diferentemente dos anarquistas, não se daria pontualmente, em um curto prazo; a revolução é um processo, eis aí o movimento que levaria ao desvanecimento do Estado. Na sociedade comunista, a liberdade seria característica fundamental e se daria como realização da emancipação humana, e nesse sentido, a cientista política Thamy Pogrebinschi (2009, p. 197) acredita que "a liberdade que se tem na comunidade existe precisamente por causa da comunidade e significa exatamente ser membro dela. 0 indivíduo é livre na exata medida em que é membro de uma comunidade livre. Liberdade significa liberdade na comunidade". E a autora segue afirmando que "associados, na forma de comunidade, os homens, livres, podem agora realizar suas 'necessidades mais elevadas': é chegada a hora da democracia. Ou melhor, encontrado seu lugar, é chegado o momento do político: a verdadeira democracia" (POGREBINSCHI, 2009, p. 198).

Ao que parece, o fortalecimento do ser político se daria e, simultaneamente, levaria à superação do Estado, assim chegaríamos ao sentido da verdadeira democracia. Marx acreditava que a democracia teria seu fundamento nas noções de autodeterminação e autogoverno, escapando, assim, da alienação. É preciso que o povo intervenha diretamente na realidade. É dessa maneira que, intervindo na realidade, a autodeterminação aliaria atividade e criatividade. 0 autogoverno é exercido em ambas as esferas que constituem a comunidade, seja a pública ou a privada.

Nada disso é simples, e o tamanho restrito deste artigo não nos permite aprofundar o debate de maneira necessária, entretanto convém esclarecer que a noção de autodeterminação tem um caráter coletivo, de compartilhamento de pensamentos e de ações. Tratase da determinação de si, mas também, ao mesmo tempo, da sociedade; ou seja, é simultaneamente determinação singular e coletiva, individual e do povo, já que o ser individual e a comunidade se inter-relacionam formando um singular coletivo. 0 todo e as partes são autoconstituintes. Por isso é factível falarmos em autodeterminação no sentido em que a determinação de um influencie a determinação do outro, o que leva Pogrebinschi (2009, p. 222) a afırmar que "a associação faz com que os indivíduos formem com a comunidade um múltiplo uno".

A cidadania torna-se prática democrática dos seres humanos através de sua própria forma de constituição política; ou seja, todas as ações são ações políticas, e, lembra-nos Pogrebinschi (2009, p. 224), "todas as atividades individuais passam a ter um sentido público, dizem respeito à gestão coletiva da comunidade". E aqui, aproximamo-nos da ideia de autogoverno, pois se cada indivíduo se governa, ele está simultaneamente governando a comunidade, visto que a ação individual é sempre uma ação pública e com objetivos políticos. 
A participação ganha com Marx uma outra dimensão, pois com a revalorização do homem como ser político, o exercício da verdadeira democracia leva-nos a outro patamar.

A participação torna-se algo "natural" para o ser político e, por isso, não lhe confere qualquer poder superior ou de soberano. Marx critica fortemente as instituições hierárquicas fundadas no saber dos especialistas, por isso é compreensível percebermos sua crítica à burocracia e a sua defesa da autogestão. Logo, melhor seria falar em atividade do que em funções, pois é exatamente a atividade do ser político que explicaria a autogestão, assim como o faz em relação ao autogoverno e a autodeterminação. Ou seja, Marx apresenta uma visão radical (no sentido de ir à raiz da questão) quando constrói sua noção de verdadeira democracia, visto que não aceita mediações e eleva a participação a outro patamar, pois nela os atores sociais não apenas tomam parte, eles, através da sua atividade, constituem a própria democracia. Ou seja, o ser político se realiza em sua prática e não necessariamente em instituições. Partindo deste pressuposto, Pogrebinschi (2007, p. 125) afirma que "o que define como verdadeira a democracia é a experiência humana que se encontra em sua base, e não as instituições de uma determinada forma de governo ou regime político que porventura a reclamem".

\section{Considerações finais... ou isso está apenas começando...}

Aqui importa esclarecer que não se trata do resgate de Karl Marx de forma dogmática, sem ter em mente que ele viveu na Europa do século XIX; e falava principalmente a partir da realidade Alemã, Inglesa e Francesa. Marx, à época, colocou em questão certezas estabelecidas na Filosofia, Economia Política etc. Com certeza, atualmente, não poderíamos pensar em uma forma apenas horizontal de gestão; é preciso caminhar na conjugação de formas horizontais e verticais, mas é preciso fortalecer a participação a partir da criação de conselhos de bairros e conselhos temáticos. Mas não devemos "eternizar" os participantes desses conselhos, é preciso que haja sempre um revezamento. Devem ser os conselhos a definir as propostas e necessidades e não o vereador ou o deputado. Estes devem "apenas" representar a posição e o desejo da população, porque atualmente não é isso o que acontece realmente. Esses políticos têm dado muito mais voz aos financiadores de suas campanhas do que à população de forma geral.

Participação não significa reunir algumas dezenas ou centenas de pessoas e apresentar-Ihes um projeto de intervenções urbanas ou apresentar-lhes o que será realizado. Isso definitivamente não é participação; é praticamente apenas uma forma de publicidade em duplo sentido: o primeiro ao apresentar as propostas do governo, e o segundo, no sentido de fazer crer que o governo implementa a participação popular.

Participar não se limita a opinar sobre um determinado projeto, supõe também a vontade de intervir na produção do espaço; a participação cidadã, como já vimos afirmando há mais de uma década, conecta a pessoa com a coisa pública e isso não deve acontecer apenas nos marcos institucionais do Estado, deve partir da sociedade organizada. E se tivermos em conta o que anteriormente trouxemos, a partir da interlocução com Karl Marx, acerca da participação, todas as atividades individuais passam a ter um sentido público, já que dizem respeito à gestão coletiva da comunidade. É preciso romper com o cotidiano a que somos submetidos. Precisamos resgatar a humanidade do ser humano, a luta pela transformação do estado de coisas atual não tem que continuar gastando energia na busca do "sujeito da transformação", que durante algum tempo teve o nome de proletariado. A emancipação, a transformação do estado de coisas atual deve ter como base o próprio Homem, e, nesse sentido, é também uma autoemancipação. Talvez seja por isso que Marx acreditava que ser radical significava compreender as coisas pela raiz, mas para o ser humano, a raiz é o próprio Homem.

É preciso construir propostas de mudanças nos processos de decisão, mas também relativas à construção de espaços - no sentido concreto mesmo de diálogo e de decisões, visto que, de alguma maneira, nós produzimos o espaço que nos produz. Para tanto, é preciso pensarmos o espaço também como política. Há mundo afora sinais de que é possível construirmos esses espaços; inclusive através de exemplos concretos que resgatam as ideias de bens comuns, de espaços comuns, de participação e de autogestão. Áreas das cidades muitas vezes abandonadas pelo poder público são apropriadas pela população do lugar e ganham características de espaço de todos, cuja gestão é produzida de maneira intensa, aberta e participativa. Trata-se daquilo a que Marx (1998, p. 19), há tempos, referira-se como "o movimento autônomo da imensa maioria no interesse da imensa maioria". Entretanto, guardaremos esses exemplos para um outro momento. Propostas desafiadoras! Mas por tudo isso acreditamos que vale a pena lutar pelo impossível possível do qual nos falava Henri Lefebvre $(1991,2001)$. 


\section{Referências}

ALTHUSSER, Louis. For Marx. New York, Pantheon Books, 1969.

BORON, Atilio A. Filosofia política e crítica da sociedade burguesa: O legado teórico de Karl Marx. In Boron, Atilio A. Filosofia política moderna. De Hobbes a Marx. São Paulo: CLACSO, Consejo Latinoamericano de Ciencias Sociales, DCP-FFLCH, USP, 2006.

CAPEL, Horacio. La Cosmópolis y la ciudad. Barcelona: del Serbal, 2003. 248p.

CARLOS, Ana Fani Alessandri. Em nome da cidade (e da propriedade). In Anais do XIV Coloquio Internacional de Geocrítica - Las utopias y la construcción de la sociedad del futuro. Barcelona, 2-7 de mayo de 2016. http://www. ub.edu/geocrit/xiv-coloquio/AnaFaniCarlos.pdf

CASTORIADIS, Cornelius. A instituição imaginária da sociedade. Rio de Janeiro: Paz e Terra, 1982.

DARDOT, Pierre, LAVAL, Christian. A nova razão do mundo: ensaio sobre a sociedade neoliberal. São Paulo: Boitempo, 2016.

FERREIRA, Alvaro. A luta pela "verdadeira democracia" na produção do espaço: por outro projeto de sociedade. In FERREIRA, Alvaro, RUA, João, MATTOS, Regina Célia de (orgs.). Produção do espaço: emancipação social, o comum e a "verdadeira democracia". Rio de Janeiro: Consequência, 2019, p. 23-54.

GOLDMANN, Lucien. A reificação das relações sociais. In FORACCHI, Marialice Mencarini, MARTINS, José de Souza. Sociologia e sociedade: Leituras de introdução à Sociologia. Rio de Janeiro: LTC, 1977, p. 137-146.

LEFEBVRE, Henri. La producción del espacio. Madrid: Capitán Swing, 2013.

LEFEBVRE, Henri. A cidade do capital. Rio de Janeiro: DP\&A, 2001.

LEFEBVRE, Henri. A revolução urbana. Belo Horizonte: UFMG, 1999.

LEFEBVRE, Henri. O direito à cidade. São Paulo: Moraes, 1991.

LÖWY, Michael. A teoria da revolução no jovem Marx. São Paulo: Boitempo, 2012.

MARX, Karl. Crítica do programa de Gotha. São Paulo: Boitempo, 2012.

MARX, Karl. A guerra civil na França. São Paulo: Boitempo, 2011.

MARX, Karl. O Dezoito Brumário de Louis Bonaparte. 5. Ed. São Paulo: Centauro, 2006.

MARX, Karl. Crítica da filosofia do direito de Hegel. São Paulo: Boitempo, 2005.

MARX, Karl. Manuscritos Econômicos-Filosóficos. São Paulo: Boitempo, 2004.

MARX, Karl; ENGELS, Friedrich. Manifesto do Partido Comunista. In: REIS FILHO, Daniel Aarão (org.). O Manifesto Comunista 150 anos depois. Rio de Janeiro: Contraponto; São Paulo: Perseu Abramo, 1998, p. 7-41.

POGREBINSCHI, Thamy. O enigma do político: Marx contra a política moderna. São Paulo: Boitempo, 2009.

POGREBINSCHI, Thamy. O político contra a política: uma agenda de pesquisa em forma de manifesto. Sinais Sociais, v.2, n.4, Maio-Agosto, 2007.

SANTOS, Boaventura de Sousa. Pela mão de Alice. 3. Ed. São Paulo: Cortez, 1997.

SOUZA, Marcelo Lopes de. Por uma Geografia Libertária. Rio de Janeiro: Consequência, 2017. 